\title{
A könyvtári szolgáltatások átalakulása és fejlesztése a pandémia idején
}

\author{
Békésiné Bognár Noémi Erika \\ Országos Széchényi Könyvtár, Könyvtári Intézet, Kutatási és Elemző Osztály \\ bognar.noemi@oszk.hu
}

Nagy Andor

Országos Széchényi Könyvtár, Könyvtári Intézet, Kutatási és Elemző Osztály nagy.andor@oszk.hu

\begin{abstract}
The Covid19 pandemic has not only posed new difficulties to libraries but has accelerated the process of digitizing library services. Although different services, events and information sources online were only an option for libraries before, in 2020 it became essential for them to be able to fulfill their purpose even during obligatory closures: preserving human culture, making it accessible, providing information ensuring equal opportunities. Librarians all over the world re-evaluated their duties and tasks, the forms of communication and tools used.

In January 2021, we conducted a survey of Hungarian libraries at the Research and Analysis Department of the Hungarian Library Institute, during which we tried to explore how certain library services and background activities changed during the pandemic. Based on the obtained results, it can be said that the operation of libraries not only did not stop during the obligatory closure of library buildings, but many libraries began to develop electronic and remote services on a large scale and tried to ensure that they could serve their users during this period. Not only by making some information sources available online and re-prioritizing tasks, but also by digitizing events, trainings, exhibitions and mainly locally available services.
\end{abstract}

Keywords: library service, digitization, digital transformation, remote access, pandemic, covid19

\section{Bevezetés}

Az 1997. évi 140. törvény ${ }^{1}$ megfogalmazása szerint, az információs társadalom és a demokratikus jogállam múködésének alapfeltétele a könyvtári rendszer, amelynek alapvető feladata az információk szabad hozzáférhetőségének biztosítása. A 2020 elején kirobbanó világjárvány és az azt követő korlátozó intézkedések megnehezítették ezen feladat ellátását, ám a felméréseink alapján a szolgáltatás a kényszerú zárvatartás idején sem szünetelt. A könyvtárak olyan intézkedéseket hoztak, amelyek nem csupán újszerűségükkel tűntek ki, de sok közülüka könyvtári rendszer hosszútávú fennmaradását is támogathatja.

1 1997. évi CXL. törvény a muzeális intézményekről, a nyilvános könyvtári ellátásról és a közmúvelődésröl, 2021. Hozzáférés: 2021. 05. 31. https://net.jogtar.hu/jogszabaly?docid=99700140.tv 
A Könyvtári Intézet Kutatási és Elemző Osztályán 2021 januárjában egy felmérést készítettünk a magyarországi könyvtárak és KSZR szolgáltatóhelyek körében², amelynek során azt kíséreltük meg feltárni, hogy miképp alakultak át az egyes könyvtári szolgáltatások és háttértevékenységek a pandémia idején, így helyzetképet adva a magyarországi könyvtárak jelenlegi müködéséről. Mostani tanulmányunk ennek a kutatásnak az előzményeit, a céljait, az alkalmazott módszereit és az eredményeit foglalja össze röviden.

A koronavírus-járvány eddig nem tapasztalt emberi és szakmai kihívások elé állított mindannyiunkat. Megváltoztak a munkakörülmények: mind a könyvtárosoké, mind az olvasóké. A korlátozások idején főleg az otthon tanuló diákokat, hallgatókat, az otthonról tanító pedagógusokat, tanárokat és a home officeban dolgozó felnőtteket kellett kiszolgálni. Mivel Magyarországon a könyvtári szolgáltatásokra a veszélyhelyzet idején is megmaradt az igény, így a hazai könyvtárak igyekeztek minden elérhető eszközt megragadni a könyvtárhasználók kiszolgálására. A 2020 márciusa óta tartó időszak legnagyobb részében fizikai tereiknek a bezárására kényszerültek a könyvtárak, azonban ez nem jelentett szolgáltatáskiesést. Az olvasókkal való kommunikáció hagyományos módjai és a korábban megszokott szolgáltatási rend nem müködhetett tovább. Míg korábban az egyes szolgáltatások, a rendezvények és az információforrások online elérhetővé tétele csupán lehetőség volt a könyvtárak számára, addig a 20202021-es években már elengedhetetlen feltételévé vált annak, hogy a zárvatartás idején is megfelelhessenek küldetésüknek, ami az emberi kultúra megőrzése, hozzáférhetővé tétele, az információs esélyegyenlőség biztosítása.

A rendkívüli körülmények miatt, a könyvtárosok ahogy a világon mindenhol, úgy hazánkban is, újraértékelték szerepüket és a feladataikat, a szolgáltatási folyamatokat, a szolgáltatások fizikai és virtuális tereit, valamint a dokumentumok, információk eljuttatására alkalmazott kommunikációs formákat, eszközöket. Az ország könyvtárosainak felkészültsége, kreativitása és elhivatottsága révén új, a pandémiához alkalmazkodó megoldások születtek. A könyvtárak egy jelentős részének sikerült rugalmasan reagálni erre a nem várt helyzetre, és régi szolgáltatásaik átszervezésével, illetve újak kialakításával megtalálták azokat a lehetőségeket, amelyekkel a zárvatartás ellenére használóikat támogatni tudják, mind az analóg és mind a digitális tartalmak elérésében. Ebben az időszakban felértékelődött a távolról elérhető tartalom és a biztonságos könyvtárhasználat.

\subsection{A Könyvtári Intézet szerepe a koronavírus könyvtárakra gyakorolt hatásának feltérképezésében}

Az Országos Széchényi Könyvtár és a Könyvtári Intézet munkatársai, köztük mi is, arra törekszünk, hogy különböző módokon segítsük mind a könyvtáros szakma, mind az olvasók tájékozódását a pandémia idején, ezért 2020 márciusától nyomon követjük a koronavírus-járvány könyvtárakra gyakorolt hatását.

2 Békésiné Bognár Noémi Erika [et al.]: A könyvtárak és a világjárvány hullámai: gyorsjelentés a magyarországi és a határon túli könyvtárak szolgáltatásairól. Hozzáférés: 2021. 05. 31.

https://ki.oszk.hu/sites/default/files/hirfajlok/a_konyvtarak_es_a_vilagjarvany_hullamai.pdf 
A járvány újabb hullámainak megjelenésével a teljes nyitás és a korábban megszokott működési, illetve szolgáltatási rendhez való visszatérés egyelőre még várat magára, így a járvány hatására bevezetett változtatások mélyebb vizsgálata időszerűvé vált. A most bemutatott kutatásunkat több, rövidebb felmérés előzte meg: 2020 áprilisában a koronavírus megjelenése után készítettünk egy kérdőíves vizsgálatot, valamint 2020 nyarán, a könyvtárak újranyitási tapasztalatait is összegyújtöttük és megosztottuk ${ }^{3}$. $A z$ ismeretek bővítése, a mélyebb és előremutató elemzés érdekében 2021 januárjában egy újabb, reprezentatív felmérést végeztünk a hazai könyvtárak járványhelyzethez való alkalmazkodásáról. Ennek apropója az volt, hogy mindeddig kevés reprezentatív, kvantitatív jellegű publikáció született, inkább benyomásokat összegző, kvalitatív jellegűek készültek A kvantitatív kutatások legtöbbje is leíró jellegű volt, néhol a könyvtárakműködésére, néholpedig a könyvtárosokmunkakörülményeire, benyomásaira kérdeztek rá.

\section{A kutatás célja, kérdései és módszerei}

A kutatásban többet között arra kerestük a választ, hogy milyen lépéseket tettek a könyvtárak a felhasználók segítésének, elérésének, megtartásának érdekében, a digitális oktatást, az otthoni tanulást és munkavégzést hogyan tudták támogatni, milyen változások történtek a könyvtárakban a szolgáltatások müködtetését, minőségét tekintve a járványhelyzet miatt. A könyvtárvezetőket megkérdeztük arról is, hogy véleményük szerint mely szolgáltatások hiányoztak az olvasóknak, milyen a szolgáltatások megváltozott formáinak megítélése a fenntarthatóság szempontjából, továbbá, hogy hogyan változott a bezárások idején az egyes háttérmunkákra szánt munkaidő, illetve humánerőforrás-ráfordítás a könyvtárakban. Ezeket a kérdéseket vizsgáltuk könyvtártípusok szempontjából is. Részletesebben kérdeztünk rá a hazai könyvtárak járványidőszak alatt nyújtott táv- és online szolgáltatásaira, valamint a vizsgált szolgáltatások országos elterjedtségét is górcső alá vettük.

Az adatfelvételre online kérdőíves formában került sor 2021. január-február folyamán, minden, a 2019-es évről szóló könyvtári statisztikában szereplő könyvtárat és könyvtári szolgáltatóhelyet megszólítottunk. Az elemzés során összesen 689 választ tudtuk felhasználni. A minta nemválaszolásból adódó torzításait könyvtári funkciók és közigazgatási régiók szerinti súlyozással korrigáltuk. Az adatokat SPSS és PSPP programmal értékeltük ki.

\section{A kutatás eredményei ${ }^{4}$}

Kutatásunkban összegyűjtöttük azokat járványhelyzet idején hozott intézkedéseket, amelyekkel az olvasók találkozhattak, majd ezekből csoportokat alkottunk, és rákérdeztünk a válaszadóknál, hogy ezek közül melyeket alkalmazták a felhasználók elérésének, megtartásának érdekében 2020 márciusát követően.

3 A könyvtárak újranyitása a koronavírus-járványt követően. Hozzáférés: 2021. 05. 31. https://ki.oszk.hu/sites/default/files/dokumentumtar/covid_ujranyitas_O.pdf

4 Előadásunkban előzetes adatokat közöltünk, ezért az eredmények pontosítását követően a jelen tanulmányunkban közzétett adatok kismértékben eltérhetnek az előadásban elhangzottaktól. 
Tettünk valamilyen lépést Fokozott jelenlét meglévő csatornáinkon Szolgáltatásaink épületfüggetlenítése

Új szolgáltatások

Meglévő szolgáltatások digitalizációja

Új kommunikációs csatornák

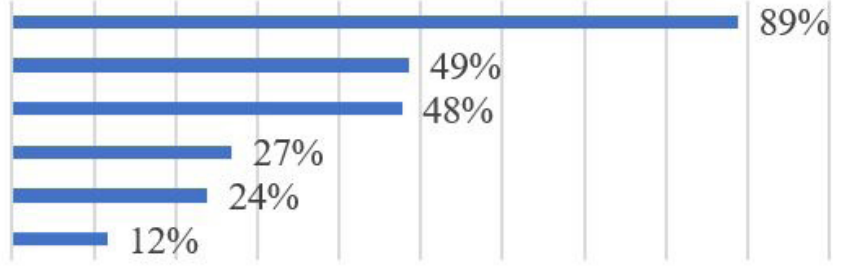

0\% $10 \%$ 20\% 30\% 40\% 50\% 60\% 70\% 80\% 90\%100\%

1. ábra. Lépések a felhasználók elérésének, megtartásának érdekében

A kapott válaszok alapján elmondható (1. ábra), hogy a könyvtárak 89\%-a fejlesztette a szolgáltatásait vagy a kommunikációját ebben az időszakban, és mindössze csak $11 \%$-uk nem tett semmilyen ez irányú lépést a járványhelyzet alatt. A legtöbben meglévő kommunikációs csatornáikon igyekeztek fokozni jelenlétüket, valamint megpróbálták szolgáltatásaikat épületfüggetlenné tenni.

Az épületfüggetlen szolgáltatás a felmérésünk alapján 46\%-ban a külső könyvátvételi pontok kialakításátjelentette(2.ábra). Ezek a könyvtáraképületén kívül elhelyezettátadóátvételi pontok, ahol a megfelelő óvintézkedések betartása mellett kölcsönözhetnek az olvasók. A könyvtárosok elöre összekészítik a kölcsönzéseket, az olvasóknak pedig csak át kell venniük azokat. $A$ visszaérkezett könyveket néhány napra karanténba helyezik. Ezenfelül a könyvtárak 42\%-a indított könyvházhozszállítás-szolgáltatást, amelynek keretén belül a könyvtárosok főként az idős vagy mozgásukban korlátozott olvasóiknak viszik házhoz a kölcsönzéseiket. Továbbá a könyvtárak közel egyharmada a járvány hatására vezette be a távoli ügyintézés lehetőségét, ám itt meg kell jegyezni, hogy ennél sokkal több könyvtárban volt elérhető ez a mód, a kapott érték csak azokra a könyvtárakra vonatkozik, amelyeknél ez egy új szolgáltatás volt.

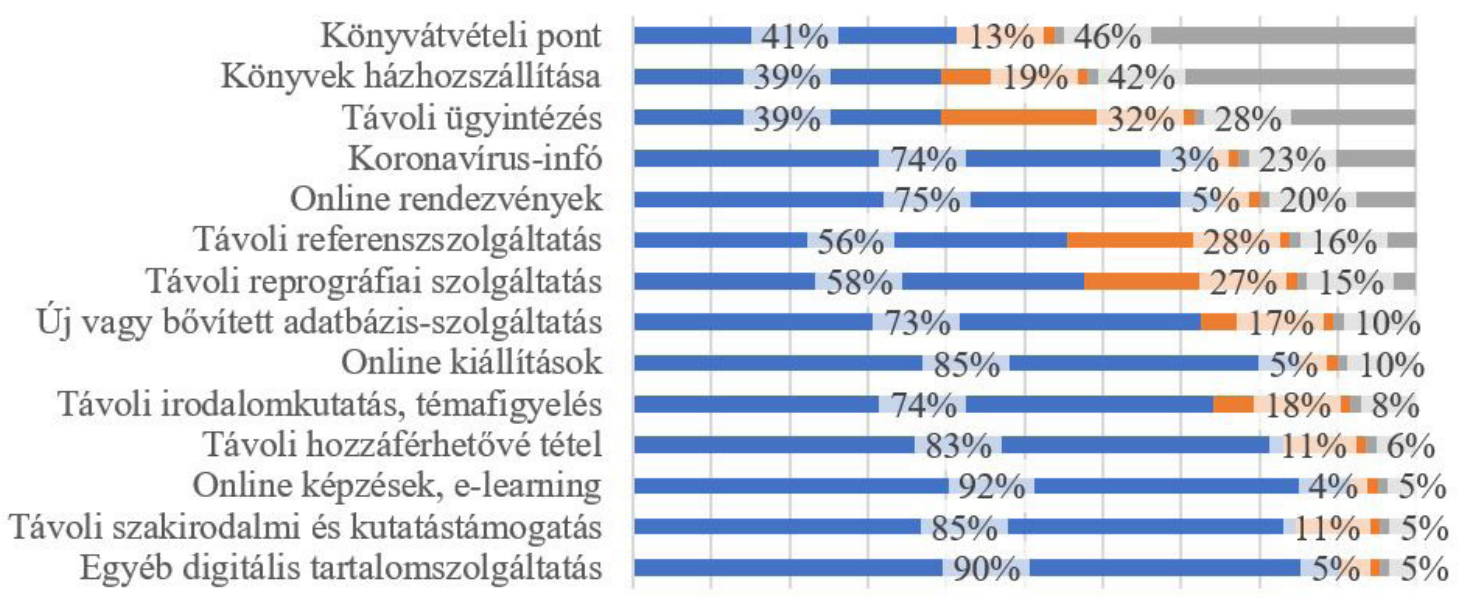

0\% 10\% 20\% 30\% 40\% 50\% 60\% 70\% 80\% 90\% $100 \%$

- Nincs ilyen szolgáltatásunk, és korábban sem volt

- A járványhelyzet elött is müködtettük

- A járványhelyzetre tekintettel elindítottuk

2. ábra. Változások a szolgáltatások múködtetését tekintve 
Évek óta nagyon látványos tendencia, hogy a könyvtárak egyre több és több rendezvényt szerveznek. Ezeknek a száma az országos könyvtári statisztika ${ }^{5}$ alapján 2019-ben már átlépte a 122 ezret, és több mint 4,5 millió látogatót vonzottak. Ide sorolhatók többek között az IT-tanfolyamok, az író-olvasó találkozók, a mesedélutánok, a baba-mama klubok, sőt még a robotika foglalkozások is.

A járvány a rendezvényeknek a számát jelentősen visszavetette, viszont a felmérésünk alapján a könyvtárak egy része rendezvényeit továbbra is megtartotta, ám könyvtártípusonként eltérő arányban. Ez az arány az egyes könyvtártípusok vonatkozásában eltérő (3. ábra), a megyei hatókörű városi könyvtárak, köztük a fóvárosi könyvtárral, több mint 70\%-a, a városi könyvtáraknak pedig több mint 49\%-a kezdett online rendezvényszervezésbe a bezárást követően. Természetesen rajtuk kívül is vannak könyvtárak, amelyekben tartottak online rendezvényeket, de esetükben nem új szolgáltatásról beszélünk, hiszen korábban is szerveztek programokat ilyen formában (Id. 3. ábra).

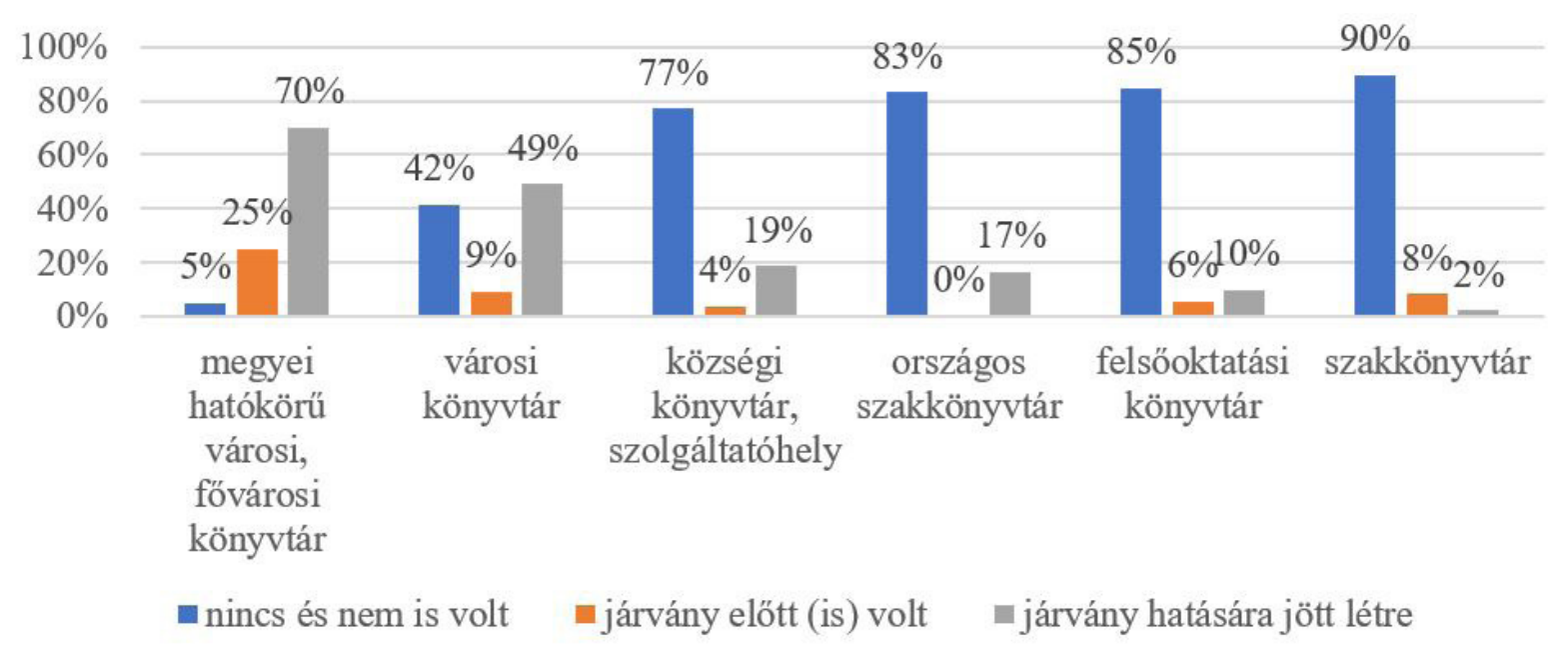

3. ábra. Online rendezvények a könyvtárakban

Már a járvány előtt is jól megfigyelhető folyamat volt, hogy az élet egyre több területe digitalizálódik, tehát vagy a meglévő szolgáltatások költöznek át a digitális térbe vagy teljesen újak jönnek létre. A pandémia ezt a folyamatot jelentősen felgyorsította, ám sok esetben kényszer szülte megoldásról van szó, ami nem biztos, hogy tartósan elérhetó marad az olvasók számára. Megkérdeztük a kérdőívünket kitöltő könyvtárvezetőket, hogy ők erról mit gondolnak. Felsoroltuk a legnépszerübb, járvány idején múködő könyvtári szolgáltatásokat, és kértük, hogy ezekről döntsék el, mi lesz a sorsuk a pandémiát követően.

A legtöbben, a válaszadók $90 \%-a$, úgy gondolja, hogy a viszonylag újszerú digitális tartalomszolgáltatásokat (pl. blog, podcast) érdemes lesz megtartani, mert nagy rájuk az igény (4. ábra). Hasonlóan vélekednek a távoli hozzáférés lehetőségéről (ide elsősorban a VPN-en és proxyn keresztüli tartalomelérés lehetőségét kell érteni), illetve a könyvtárak

5 Országos könyvtári statisztika, 2020. Hozzáférés: 2021. 05. 31.

https://ki.oszk.hu/sites/default/files/dokumentumtar/stat19hiv.xlsx 
által épített adatbázis-szolgáltatásokról. A pozitív megítélést tekintve azonban ezektől nem sokkal maradnak el a távoli reprográfiai, a kutatástámogató, és a referensz szolgáltatások, valamint az online képzések sem.

Egyéb digitális tartalomszolgáltatás

Távoli hozzáférhetővé tétel

Új vagy bővített adatbázis-szolgáltatás

Távoli referenszszolgáltatás

Online képzések, e-learning

Távoli szakirodalmi és kutatástámogatás

Távoli irodalomkutatás, témafigyelés

Online kiállítások

Könyvek házhozszállítása

Távoli ügyintézés

Online rendezvények

Könyvátvételi pont

Koronavírus-infó

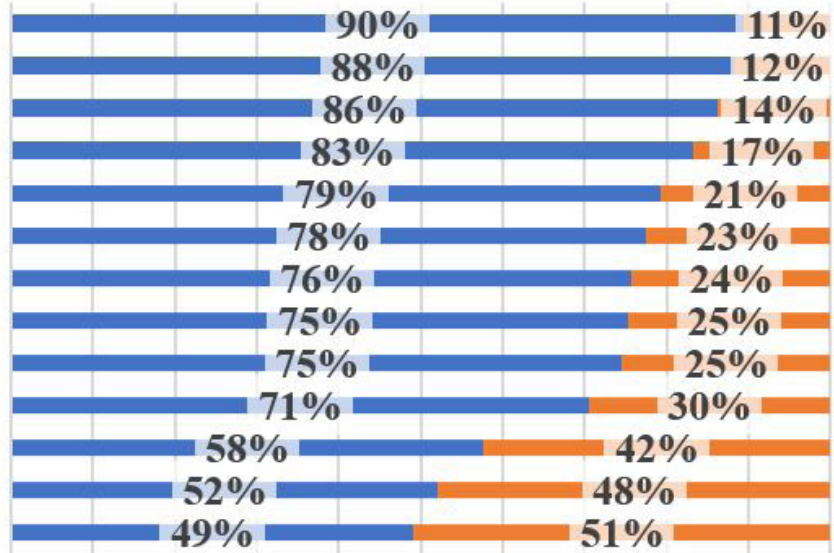

$0 \% \quad 10 \%$ 20\% 30\% 40\% 50\% 60\% 70\% 80\% 90\% $100 \%$

- érdemes lenne fenntartani, mert (ilyen formában) nagy rá az igény

= nem lenne érdemes fenntartani, mert (ilyen formában kicsi rá az igény)

4. ábra. Mit gondol, az Önök könyvtárában az alább felsorolt szolgáltatásokat érdemes lenne-e fenntartani a jelenlegi formájukban a járványhelyzet elmúltával is?

Talán a legkézzelfoghatóbb járvány szülte könyvtári szolgáltatások, amelyekkel a média is gyakran foglalkozott, a külső könyvátvételi pontok és a könyvházhozszállítás szolgáltatások voltak. A felmérésünk alapján jó esély van arra, hogy ezek a szolgáltatások - bár a kényszerú zárvatartás miatt jöttek létre - a könyvtárak egy részében a pandémia után is megmaradnak.

A könyvátvételi pontokkal kapcsolatosan a legnagyobb arányban a megyei hatókörú városi könyvtárakban és a fővárosi könyvtárban gondolják ezt így (55\%), ám amint az 5. ábrán látható, minden könyvtártípusból érkeztek olyan válaszok, amelyek alapján azt gondolhatjuk, hogy a szolgáltatás sok helyen a jövőben is elérhető lesz. 

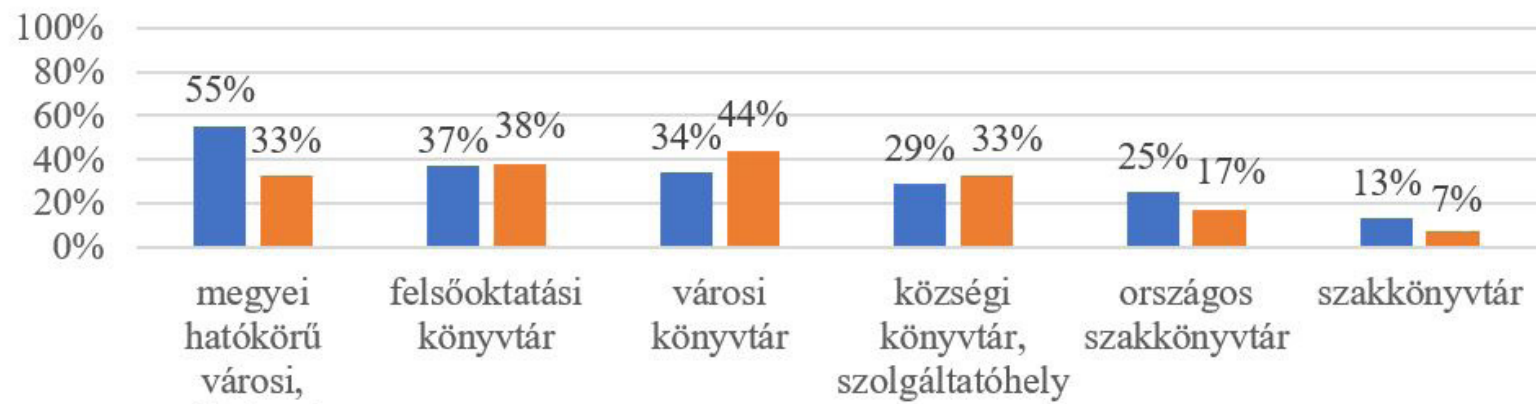

fővárosi

könyvtár

匹 érdemes lenne fenntartani, mert (ilyen formában) nagy rá az igény

nem lenne érdemes fenntartani, mert (ilyen formában kicsi rá az igény)

\section{5. ábra. Érdemes lenne-e fenntartani a könyvátvételi pontokat?}

Az összes szolgáltatás megítélését összevetve tehát úgy tűnik, hogy sok könyvtárvezető, akiknek van már tapasztalata a távoli-, illetve online szolgáltatásokkal, hosszútávon is értékes szolgáltatásoknak tartja ezeket.

A könyvtárak kapcsán fontos kérdés volt, hogy miképp fogják tudni támogatni az oktatást, a tanulást és a munkavégzést a járványhelyzet idején. A könyvtárak e szerepe jelentős, amellett, hogy foglalkoznak formális és nonformális oktatással, teret biztosítanak a tanulásnak, munkavégzésnek, illetve mindezt egyéb szolgáltatásaikkal is támogatják. Felmérésünk alapján a könyvtárak jelentős része igyekezett segíteni az otthoni oktatást, tanulást és munkavégzést.

Amint az a diagramon látszik (6.ábra), a felsőoktatási könyvtárak 100\%-a válaszolta, hogy tett lépéseket ez irányba, őket követték 93\%-kal a megyei hatókörű városi könyvtárak és a fővárosi könyvtár, a sorban a következők az országos szakkönyvtárak voltak, majd a városi, a községi könyvtárak, végül az egyéb szakkönyvtárak. A válaszokból leszűrhetjük, hogy a legtöbben a tanulási felületekről szolgáltattak információt, dokumentumokat digitalizáltak és meglévő tartalomszolgáltatási felületeiket bővítették.

felsőoktatási könyvtár megyei hatókörü városi, fövárosi könyvtár országos szakkönyvtár városi könyvtár községi könyvtár, szolgáltatóhely szakkönyvtár

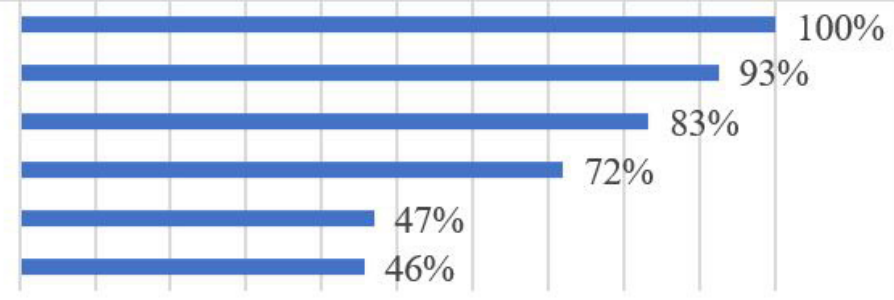

$0 \% 10 \% 20 \% 30 \% 40 \% 50 \% 60 \% 70 \% 80 \% 90 \% 100 \%$

6. ábra. Tettünk lépéseket az online tanulás és munkavégzés támogatása érdekében. 
Felmérésünk egy másik érdekes pontja azzal foglalkozott, hogy a megváltozott helyzet hogyan hatott a munkaszervezésre és háttérmunkákra. Kitöltőinknél arra kérdeztünk rá, hogy mely háttérmunkára mennyi időt fordítottak a kényszerű zárva tartás idején, és a válaszok alapján elmondható, hogy olyan tevékenység nem volt, amelyre lényegesen kevesebb időt szántak, viszont voltak olyanok, amelyekre több jutott. Ilyen volt az állományrendezés, az állománygyarapítás, az apasztás és a leltározás, tehát tipikusan azok a tevékenységek, amelyeket könnyebb elvégezni, ha nincsenek olvasók az épületben.

A kutatás során létrehoztunk egy, a könyvtárak aktivitásának megállapítására szolgáló tipológiát is, amely egy változóban szemlélteti nemcsak a könyvtárak járványhelyzetre adott reakcióit, hanem a korábbi aktivitásukat a táv- és online szolgáltatások létrehozása terén (a kérdőívben adottválaszaikalapján, amelyek a már működtetett, azújonnan indított, illetve bővített szolgáltatásokra vonatkoztak). Négy elméleti típus különböztettünk meg egymástól: passzívak, kényszerújítók, mérsékelt újítók, innovatívak.

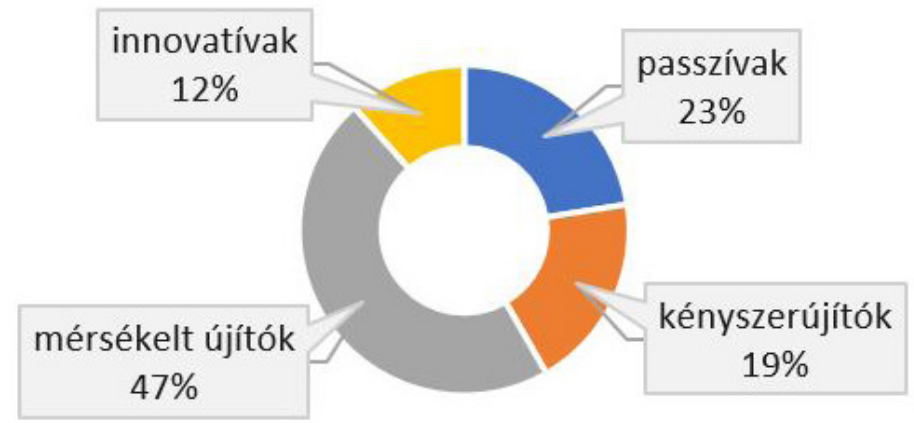

7. ábra. A könyvtárak aktivitása a táv- és online szolgáltatások terén

Eszerint (7.ábra) a magyarországi könyvtárak 47\%-a mérsékelt újító: tehát a járvány előtt is nyújtottak néhány táv-, illetve online szolgáltatást, de ezek számát a járványhelyzet hatására legfeljebb 2 új szolgáltatás bevezetésével egészítették ki. Kevésbé jellemző a könyvtárakra, hogy a járvány előtt egyetlen egyet sem biztosítottak az általunk felsorolt táv-, illetve online szolgáltatások közül és a járvány hatására is csak legfeljebb kettőt indítottak el (passzívak, 23\%), valamint az is, hogy a járvány hatására hármat vagy akár többet is elindítottak (kényszerújítók, 19\%). A legkisebb százalékban mondhatjuk innovatívnak (12\%) a könyvtárakat (a koronavírus járványt megelőzően is legalább 3 szolgáltatást biztosítottak, de a megváltozott környezet kihívásaira reagálva ezek számát még legalább 3 új bevezetésével bővítették).

\section{4. Összefoglalás}

A pandémia járulékos hatásai minden jel szerint felgyorsították a táv-, illetve online szolgáltatások terjedését, és olyan új szolgáltatások létrehozására ösztönözték a könyvtárakat, amelyek vagy csak jóval később, vagy egyáltalán nem jöttek volna létre. Annak érdekében, hogy a könyvtárak olvasóikat a zárva tartás idején is képesek legyenek elérni és kiszolgálni, nagymértékben fokozták online kommunikációjukat, valamint a kölcsönzést és az ezzel kapcsolatos ügyintézést próbálták épületfüggetlenné tenni, 
hagyományos szolgáltatásaik jelentős részét digitalizálták. Mindezek mellett fontos megjegyezni, hogy hiába fektettek a könyvtárak jelentős energiát újfajta szolgáltatásaik kialakítására, egyes funkcióik elkerülhetetlenül csorbultak. Ezek elsősorban a közösségi funkciók, és azoknak a könyvtárhasználóknak a kiszolgálása, akik számára nem, vagy csak korlátozottan érhetők el IKT eszközök és az internet. Jó példa erre, hogy az aprófalvak könyvtári ellátásáért felelős könyvtárbuszok a pandémia egy jelentős időszakában nem közlekedtek. A kialakult helyzetnek minden bizonnyal vannak hosszútávon is pozitív járulékos következményei, viszont az alapvető könyvtári funkciók teljes körű ellátása nem lehetséges kizárólag a távoli elérésű szolgáltatások biztosítása révén.

\section{Bibliográfia}

1997. évi CXL. törvény a muzeális intézményekröl, a nyilvános könyvtári ellátásról és a közművelődésröl, 2021. Hozzáférés: 2021. 05. 31. https://net.jogtar.hu/jogszabaly?docid=99700140.tv

Békésiné Bognár Noémi Erika [et al.]: A könyvtárak és a világjárványhullámai: gyorsjelentés a magyarországi és a határon túli könyvtárak szolgáltatásairól. Hozzáférés: 2021. 05. 31. https://ki.oszk.hu/sites/default/files/hirfajlok/a_ konyvtarak_es_a_vilagjarvany_hullamai.pdf

A könyvtárak újranyitása a koronavírus-járványt követően. Hozzáférés: 2021. 05. 31. https://ki.oszk.hu/sites/default/files/dokumentumtar/covid_ujranyitas_0.pdf

Országos könyvtári statisztika, 2020. Hozzáférés: 2021. 05. 31. https://ki.oszk.hu/sites/default/files/dokumentumtar/stat19hiv.xlsx 
(ㄷ) (1)

N

우 